\title{
ANALISIS PERENCANAAN PENGADAAN KOMPONEN REM PESAWAT B737-800 NG BERDASARKAN SATUAN CYCLE DAN FLIGHT HOURS DI PT ABC
}

\author{
Komarudin $^{1}$, Djoko Suprijatmono ${ }^{2}$ \\ Program Studi Teknik Mesin, Institut Sains dan Teknologi Nasional Jakarta ${ }^{1} 2$ \\ Universitas Dian Nusantara Jakarta ${ }^{1}$ \\ email $^{1}$ : komarudin.mt@gmail.com
}

\begin{abstract}
As one of the MRO (Maintenance, Repair, Overhaul) company PT ABC had the significant problems in the last 3 years, including concerns regarding the difficulty of determining the amount of material availability and timing of procurement the material appropriate to support maintenance activities. In this case the components studied are two type brake of aircraft the first one is brake assembly and the second one is brake Goodrich which installed on B737-800 aircraft NG. Based on historical data, in last 3 years $P T A B C$ have a number of component shortage that continues to grow, in last year PT ABC had 12 unit shortage component for brake assembly and 13 unit shortage component for brake goodrich. It is gave the negative impact for company and also customer PT ABC. To overcome these problems need to be analyzed how to determine the accuracy the number of brake requests that will removal in future periods which resulting the accuracy of the flight time (dispatch reliability/delay time). The proccess in this reserach first determine the life time of brake, determine the quantity of removal brake, schedule of removal brake, account the forecast of requirement brake in next years and determine the planning of material requirement for maintenance proccess. The forecasting using single exponential smoothing methode to determine forecasting result of brake requirement in 2017. This methode consider the smallest standar error estimate of forecasting demand to get the exact result. Morever MRP (material requirement planning) methode used to determine the procurement components planning (Petition Requirement Planning) with forecasting data from previous year's demand. Based on studies result showed that the quantity of brake assembly and brake Goodrich types that should be available for the removal of as many as 13 units per each type of brake for a period in 2017, while the limit (age component) of brake assembly 38 days and 41 days for brake Goodrich and the estimation schedule of brake removal is the last date installation brake plus the actual age of brake that has determined the schedule of brake assembly in 21st of the months 12 and the 2nd of the month 11 for brake Goodrich and result are showed that MRP decrease the shortage of brake assembly 1 unit and decrease the shortage of brake goodrich 2 unit.
\end{abstract}

Keywords: time availbility, brake assembly, brake Goodrich, MRP, Exponential Smoothing

\section{LATAR BELAKANG}

Pengelolaan perawatan pesawat, mulai pengadaan suku cadang (sparepart) sampai pada perawatan (maintenance) nya tidak selalu ditangani oleh perusahaan penerbangan itu sendiri. Seperti halnya salah satu maskapai penerbangan $\mathrm{X}$ yang menyerahkan penanganan sparepart dan kebijakannya kepada anak perusahaannya yaitu perusahaan MRO (Maintenance, Repair, dan Overhaul) PT ABC. Salah satu kegiatan perusahaan MRO yaitu adanya perbaikan proses khususnya dari sisi pengadaan material atau BDP (Break Down
Part). BDP adalah material yang membentuk sebuah komponen utama.

Berdasarkan studi lapangan dan data historis yang di ada pada perusahaan, PT ABC kerap kali menemukan permasalahan yang cukup signifikan dalam 3 tahun terakhir, diantaranya mengenai kesulitan penentuan jumlah ketersediaan material dan penentuan waktu pengadaan material yang tepat, dalam hal ini komponen yang di bahas ialah brake (rem) pesawat Boeing B737-800 NG. Permasalahan ini akan berdampak pada ketepatan waktu pengadaan komponen untuk kebutuhan maintenance 
pesawat, diantaranya PT ABC mengalami shortage komponen brake assembly sebanyak 13 unit dan shortage brake goodrich sebanyak 12 unit pada periode tahun sebelumnya. Oleh karena itu, dalam penelitian ini penulis akan membahas tentang analisa pengadaan material berdasarkan tingkat utilisasi dan nilai MTBR dari data yang tercatat pada sistem perusahaan.

\section{RUMUSAN MASALAH}

Pokok permasalahan yang akan dibahas dalam penelitian ini yaitu mengenai mengenai ketidaktepatan jumlah BDP yang akan dipesan untuk proses removal selanjutnya khususnya pada komponen brake pesawat jenis Boeing 737 $800 \mathrm{NG}$.

\section{TUJUAN PENELITIAN}

1. Menentukan Umur aktual (usia pakai) brake pesawat pada periode yang akan datang

2. Mendapatkan nilai estimasi jumlah brake yang akan removal pada periode mendatang

3. Mendapatkan estimasi jadwal removal brake untuk perencanaan kebutuhan brake

4. Melakukan peramalan permintaan brake untuk periode mendatang

\section{HASIL PEMBAHASAN}

BDP yang di jadikan objek penelitian ini ialah komponen rem (brake) jenis carbon brake assembly dan brake goodrich pada pesawat B737-800 NG. Adapun tahapan yang dilakukan dalam penelitian meliputi melakukan perhitungan estimasi umur aktual brake, menentukan estimasi jadwal dan jumlah removal brake pada periode mendatang, serta melakukan perencanaan pengadaan komponen sesuai hasil peramalan dengan metode MRP. Tetapi, dalam jurnal ini akan di sajikan pengolahan data untuk tahun 2017 (data hasil forecast). Berikut akan di sajikan tahapan perhitungan pengolahan data penelitian.

\section{a. Perhitungan Umur Brake}

1) Perhitungan umur carbon brake assembly

$\mathrm{X}$ cycle : 153,26

$\mathrm{U}$ cycle : 4,08 /day

Maka :

Umur actual $=\frac{x \text { cycle }}{\text { ucyclep/day }}$

$$
\begin{aligned}
& =\frac{153,26}{4,08} \\
& =38 \text { days }
\end{aligned}
$$

2) Perhitungan umur brake goodrich

X cycle : 166,98
U cycle : 4,08/day

Maka :

$$
\begin{aligned}
\text { Umur actual } & =\frac{x \text { cycle }}{\text { ucycle/day }} \\
=\frac{166,98}{4,08} & =40,94 \approx 41 \text { days }
\end{aligned}
$$

\section{b. Estimasi Jadwal Removal Brake}

Berdasarkan hasil Perhitungan estimasi removal brake merupakan perhitungan kapan batas waktu atau jadwal penggantian/penurunan brake untuk periode selanjutnya.

Berikut Formulasi Perhitungannya :

$($ DDMMYY-2 $)=($ DDMMYY-1 $)+$ umur brake Berikut akan di jabarkan estimasi perhitungan jadwal removal brake :

1) Brake Assembly

(DDMMYY-1) : 15 November 2016

umur brake : 36 hari

maka :

$($ DDMMYY-2 $)=($ DDMMYY-1 $)+$ umur brake

$$
\begin{aligned}
& =15 / 11 / 2016+36 \text { hari } \\
& =21 / 12 / 2016
\end{aligned}
$$

2) Brake Goodrich

(DDMMYY-1) : 2 November 2016

umur brake : 36 hari

maka :

$($ DDMMYY-2 $)=($ DDMMYY-1 $)+$ umur brake

$$
\begin{aligned}
& =2 / 11 / 2016+39 \text { hari } \\
& =11 / 12 / 2016
\end{aligned}
$$

\section{c. Perhitungan Estimasi Jumlah Removal}

Selanjutnya dilakukan perhitungan estimasi removal brake berdasarkan data MTBR (Mean Time Between Removal) brake assembly dan brake goodrich sebagai berikut

1) Perhitungan Estimasi Removal Carbon Brake Assembly Tahun 2017

Diketahui data perhitungan hasil forecast untuk tahun 2017 sebagai berikut :

$\mathrm{QPA}=4$

Fleet Size $=1$ (pesawat B737-800 NG)

$\mathrm{FH} / \mathrm{year}=3546$

MTBR Standar $=1106,48$

Maka :

$$
\begin{aligned}
\mathrm{R} / \mathrm{year} & =\frac{\text { QPAX Flest Size (FH per AC per year) }}{\text { MTER }} \\
& =\frac{4 \times 1 \times \mathrm{x} 2546}{1106,48}=12,81 \approx 13 \text { brake/year }
\end{aligned}
$$

2) Perhitungan Estimasi Removal Brake GoodrichTahun 2017 :

Diketahui data perhitungan hasil forecast untuk tahun 2017 sebagai berikut :

$\mathrm{QPA}=4$

Fleet Size $=1$ (pesawat B737-800 NG)

$\mathrm{FH} / \mathrm{year}=3546$

MTBR Standar $=1050,67$

Maka :

$\mathrm{R} / \mathrm{year}=\frac{Q P A X \text { Fleet size }(A H \text { per } A C \text { per year) }}{\text { MTBR }}$ 


$$
\begin{aligned}
& =\frac{4 X 1 X 7546}{1050,67} \\
& =13,49 \approx 13 \text { brake/year }
\end{aligned}
$$

Tahapan selanjutnya adalah perhitungan peramalan brake yang di butuhkan utuk proses maintenance selanjutnya. Dalam alam penelitian ini penulis membandingkan metode regresi linier dengan metode exponential smoothing. Adapun data yang digunakan untuk melakukan peramalan adalah data pada periode januari 2016 sampai dengan desember 2016. Berikut akan di sajikan peramalan untuk brake assembly dan brake goodrich :

\section{d. PeramalanKebutuhan Brake Regresi Linier}

\section{1) Peramalan Brake Assembly}

Contoh Perhitungan Forecast Brake Assembly

Misal Forecast Bulan Januari

$\mathrm{F}^{\prime}(\mathrm{t})=\mathrm{a}+(\mathrm{b} \times \mathrm{t})$

$$
\begin{aligned}
& =4,409+(0,013 \times 1) \\
& =4,409+0,013 \\
& =4,422 \approx 4
\end{aligned}
$$

Misal Forecast Bulan Juli :

$$
\begin{aligned}
\mathrm{F}^{\prime}(\mathrm{t})= & \mathrm{a} \\
& +(\mathrm{b} \times \mathrm{t}) \\
& =4,409+(0,013 \times 7) \\
& =4,409+0,091 \\
& =4,5 \approx 5
\end{aligned}
$$

Hasil Perhitungan Lengkap dapat dilihat pada tabel berikut :

Tabel 4.1 Forecasting Brake Assembly Metode Regresi Linier

\begin{tabular}{|c|c|c|c|c|}
\hline $\begin{array}{c}\text { Periode } \\
(\mathbf{T})\end{array}$ & $\begin{array}{c}\text { Demand } \\
\mathbf{D}(\mathbf{t})\end{array}$ & $\left(\mathbf{T}^{\wedge} \mathbf{2}\right)$ & $\left(\mathbf{T}^{*} \mathbf{D}(\mathbf{t})\right.$ & $\begin{array}{c}\text { Forecast } \\
\mathbf{D}^{\prime}(\mathbf{t})\end{array}$ \\
\hline 1 & 4 & 1 & 4 & 4 \\
\hline 2 & 3 & 4 & 6 & 4 \\
\hline 3 & 5 & 9 & 15 & 4 \\
\hline 4 & 5 & 16 & 20 & 4 \\
\hline 5 & 4 & 25 & 20 & 4 \\
\hline 6 & 5 & 36 & 30 & 4 \\
\hline 7 & 6 & 49 & 42 & 5 \\
\hline 8 & 5 & 64 & 40 & 5 \\
\hline 9 & 5 & 81 & 45 & 5 \\
\hline 10 & 4 & 100 & 40 & 5 \\
\hline 11 & 5 & 121 & 55 & 5 \\
\hline 12 & 3 & 144 & 36 & 5 \\
\hline
\end{tabular}

1) Peramalan Brake Goodrich

Misal Forecast Bulan Januari :

$$
\begin{aligned}
& \mathrm{F}^{\prime}(\mathrm{t})=\mathrm{a}+(\mathrm{b} \times \mathrm{t}) \\
& =4,848+(-0,027 \times 1) \\
& =4,848+-0,027 \\
& =4,861 \approx 5
\end{aligned}
$$

Misal Forecast Bulan April :

$$
\begin{aligned}
& \mathrm{F}^{\prime}(\mathrm{t})=\mathrm{a}+(\mathrm{b} \times \mathrm{t}) \\
& =4,848+(-0,027 \mathrm{x} 4) \\
& =4,848+(-0,108) \\
& =4,74 \approx 5
\end{aligned}
$$

Hasil Perhitungan Lengkap dapat dilihat pada tabel berikut :

Tabel 4.2 Forecasting Brake Assembly Metode Regresi Linier

\begin{tabular}{|c|c|c|c|c|}
\hline $\begin{array}{c}\text { Periode } \\
(\mathbf{T})\end{array}$ & $\begin{array}{c}\text { Demand } \\
\mathbf{D}(\mathbf{t})\end{array}$ & $\left(\mathbf{T}^{\wedge} \mathbf{2}\right)$ & $(\mathbf{T} \mathbf{x D}(\mathbf{t})$ & $\begin{array}{c}\text { Forecast } \\
\mathbf{D}^{\prime}(\mathbf{t})\end{array}$ \\
\hline 1 & 5 & 1 & 5 & 5 \\
\hline 2 & 6 & 4 & 12 & 5 \\
\hline 3 & 4 & 9 & 12 & 5 \\
\hline 4 & 4 & 16 & 16 & 5 \\
\hline 5 & 3 & 25 & 15 & 5 \\
\hline 6 & 5 & 36 & 30 & 5 \\
\hline 7 & 6 & 49 & 42 & 5 \\
\hline 8 & 4 & 64 & 32 & 5 \\
\hline 9 & 6 & 81 & 54 & 5 \\
\hline 10 & 5 & 100 & 50 & 5 \\
\hline 11 & 4 & 121 & 44 & 5 \\
\hline 12 & 4 & 144 & 48 & 5 \\
\hline
\end{tabular}

\section{e. Peramalan Metode Exponential Smoothing}

\section{1) Brake Assembly}

Tahapan Awal metode exponential Smoothing ialah menentukan nilai croston alpha untuk nilai kesalahan permalan. Berikut akan disajikan tabel nilai alpha yang digunakan dalam perhitungan peramalan:

Tabel 4.3 Nilai Croston Alpha

\begin{tabular}{|c|rc|c|}
\hline No & \multicolumn{2}{|c|}{ Nilai Croston Alpha } & MAD \\
\hline 1 & & $\alpha=0,1$ & $-0,01$ \\
\hline 2 & & & $-0,04$ \\
\hline 3 & & & $-0,07$ \\
\hline 4 & & $\alpha=0,4$ & $-0,09$ \\
\hline 5 & $\alpha=0,5$ & & -0.10 \\
\hline 6 & & $\alpha=0,6$ & $-0,11$ \\
\hline 7 & $\alpha=0,7$ & & -1.11 \\
\hline 8 & $\alpha=0,8$ & & $-1,18$ \\
\hline 9 & $\alpha=0,9$ & & $-1,21$ \\
\hline
\end{tabular}

Dari tabel di atas dapat diketahui bahwa nilai standar error terkecil (MAD) ialah -1,21 dengan nilai Alpha 0,9, maka dapat dilakukan perhitungan nilai forecast dengan menggunakan alpha 0,9. Berikut akan di sajikan contoh perhitungan forecast dengan metode exponential smoothing

Misal :

Forecast Bulan Febuari :

$F^{\prime}(t)=\alpha^{*} F t+(1-\alpha)^{*} F^{\prime}(t-1)$ 


$$
\begin{gathered}
=(0,9 \times 5)+(1-0,9) \times 5 \\
=4,5+0,5 \\
=5
\end{gathered}
$$

Forecast Bulan September :

$$
\begin{aligned}
\mathrm{F}^{\prime}(\mathrm{t}) & =\alpha^{*} \mathrm{Ft}+(1-\alpha) * \mathrm{~F}^{\prime}(\mathrm{t}-1) \\
& =(0,9 \times 5)+(1-0,9) \times 6 \\
& =4,5+0,6 \\
& =5,1 \approx 5
\end{aligned}
$$

Hasil Perhitungan lengkap dapat dilihat pada tabel di bawah

Tabel 4.4 Forecast Brake Assembly

\begin{tabular}{|l|l|l|c|c|}
\hline No & Month & $\begin{array}{l}\text { LT } \\
\text { (hari) }\end{array}$ & $\begin{array}{l}\text { Demand } \\
\text { (Unit) }\end{array}$ & $\begin{array}{l}\text { Forecast } \\
\text { (Unit) }\end{array}$ \\
\hline 1 & Januari & 15 & 4 & 5 \\
\hline 2 & Febuari & 15 & 3 & 4 \\
\hline 3 & Maret & 15 & 5 & 3 \\
\hline 4 & April & 15 & 5 & 5 \\
\hline 5 & Mei & 15 & 4 & 5 \\
\hline 6 & Juni & 15 & 5 & 4 \\
\hline 7 & Juli & 15 & 6 & 5 \\
\hline 8 & Agustus & 15 & 5 & 6 \\
\hline 9 & September & 15 & 5 & 5 \\
\hline 10 & Oktober & 15 & 4 & 5 \\
\hline 11 & November & 15 & 5 & 4 \\
\hline 12 & Desember & 15 & 3 & 5 \\
\hline
\end{tabular}

\section{2) Brake Goodrich}

Tahapan Awal metode exponential Smoothing ialah menentukan nilai croston alpha untuk nilai kesalahan permalan. Berikut akan disajikan tabel nilai alpha yang digunakan dalam perhitungan peramalan :

Tabel 4.5 Nilai Croston Alpha

\begin{tabular}{|c|c|c|}
\hline NO & Nilai Croston Alpha & MAD \\
\hline 1 & $\alpha=0,1$ & $-0,043$ \\
\hline 2 & $\alpha=0,2$ & $-0,056$ \\
\hline 3 & $\alpha=0,3$ & $-0,060$ \\
\hline 4 & $\alpha=0,4$ & $-0,0616$ \\
\hline 5 & $\alpha=0,5$ & -0.0618 \\
\hline 6 & $\alpha=0,6$ & $-0,0611$ \\
\hline 7 & $\alpha=0,7$ & $-0,0594$ \\
\hline 8 & $\alpha=0,8$ & $-0,0570$ \\
\hline 9 & $\alpha=0,9$ & $-0,0530$ \\
\hline
\end{tabular}

Dari tabel di atas dapat diketahui bahwa nilai standar error terkecil (MAD) ialah 0,0618 dengan nilai Alpha 0,5, maka dapat dilakukan perhitungan nilai forecast dengan menggunakan alpha 0,5. Berikut akan di sajikan contoh perhitungan forecast dengan metode exponential smoothing

Forecast Bulan Febuari :

$$
\begin{aligned}
\mathrm{F}^{\prime}(\mathrm{t}) & =\alpha * \mathrm{Ft}+(1-\alpha) * \mathrm{~F}^{\prime}(\mathrm{t}-1) \\
& =(0,9 \times 6)+(1-0,9) \times 5 \\
& =5,4+0,5 \\
& =5,9 \approx 6
\end{aligned}
$$

Forecast Bulan Desember :

$$
\begin{aligned}
\mathrm{F}^{\prime}(\mathrm{t}) & =\alpha * \mathrm{Ft}+(1-\alpha) * \mathrm{~F}^{\prime}(\mathrm{t}-1) \\
& =(0,9 \times 4)+(1-0,9) \times 5 \\
& =3,6+0,5 \\
& =4,1 \approx 4
\end{aligned}
$$

Hasil Perhitungan lengkap dapat dilihat pada tabel di bawah

Tabel 4.6 Forecast Brake Goodrich

\begin{tabular}{|l|l|l|c|c|}
\hline No & Month & $\begin{array}{l}\text { LT } \\
\text { (hari) }\end{array}$ & $\begin{array}{l}\text { Demand } \\
\text { (Unit) }\end{array}$ & $\begin{array}{l}\text { Forecast } \\
\text { (Unit) }\end{array}$ \\
\hline 1 & Januari & 15 & 5 & 5 \\
\hline 2 & Febuari & 15 & 6 & 5 \\
\hline 3 & Maret & 15 & 4 & 5 \\
\hline 4 & April & 15 & 4 & 5 \\
\hline 5 & Mei & 15 & 4 & 4 \\
\hline 6 & Juni & 15 & 5 & 4 \\
\hline 7 & Juli & 15 & 5 & 5 \\
\hline 8 & Agustus & 15 & 4 & 5 \\
\hline 9 & September & 15 & 5 & 4 \\
\hline 10 & Oktober & 15 & 5 & 5 \\
\hline 11 & November & 15 & 4 & 5 \\
\hline 12 & Desember & 15 & 4 & 4 \\
\hline
\end{tabular}

\section{f.Perencanaan Dengan MRP}

Data yang di pakai dalam MRP ialah data peramalan permintaan yang ,serta data jumlah persediaan yang ada dan periode perencanaan material Berdasarkan perhitungan dengan menggunakan Microsoft excel maka di dapatkan hasil perhitungan seperti pada tabel selanjutnya :

1) MRP Brake Assembly

a) Input Sistem MRP

Tabel 4.7 MPS Brake Asssembly

\begin{tabular}{|l|l|l|l|l|l|l|l|l|l|l|l|l|}
\hline Periode & 1 & 2 & 3 & 4 & 5 & 6 & 7 & 8 & 9 & 10 & 11 & 12 \\
\hline $\begin{array}{l}\text { Brake } \\
\text { Goodrich }\end{array}$ & 5 & 4 & 3 & 5 & 5 & 4 & 5 & 6 & 5 & 5 & 4 & 5 \\
\hline
\end{tabular}


Tabel 4.8 Data Persediaan Brake Assembly

\begin{tabular}{|c|c|}
\hline Bulan & $\begin{array}{c}\text { Stock On Hand,Schedule } \\
\text { Receipt,AI Stock }\end{array}$ \\
\hline Januari & 1 \\
\hline Febuari & 4 \\
\hline Maret & 4 \\
\hline April & 5 \\
\hline Mei & 4 \\
\hline Juni & 4 \\
\hline Juli & 4 \\
\hline Agustus & 4 \\
\hline September & 4 \\
\hline Oktober & 4 \\
\hline November & 4 \\
\hline Desember & 5 \\
\hline
\end{tabular}

\section{b) Output Sistem MRP}

Tabel 4.9 MRP Brake Assembly

\begin{tabular}{|c|c|c|c|c|c|c|c|c|c|c|c|c|c|}
\hline \multicolumn{5}{|c|}{ Minimum Stock $=2$} & \multicolumn{8}{|c|}{ Maksimum Stock $=4 \quad$ ROP $=3$} & \multirow{2}{*}{$\frac{\text { Total }}{12}$} \\
\hline $\begin{array}{c}\text { Bulan } \\
\text { (Periode) }\end{array}$ & 1 & 2 & 3 & 4 & 5 & 6 & 7 & 8 & 9 & 10 & 11 & 12 & \\
\hline $\begin{array}{c}\text { Demand } \\
\text { (Unit) }\end{array}$ & 5 & 4 & 3 & 5 & 5 & 4 & 5 & 6 & 5 & 5 & 4 & 5 & 56 \\
\hline $\begin{array}{c}\text { On } \\
\text { Hand,AI } \\
\text { Stock,Sche } \\
\text { dule } \\
\text { Receipt(uni } \\
\text { t) } \\
\end{array}$ & 1 & 4 & 4 & 5 & 4 & 4 & 4 & 4 & 4 & 4 & 4 & 4 & 0 \\
\hline $\begin{array}{c}\text { Replenishm } \\
\text { ent (unit) }\end{array}$ & & 4 & 4 & 4 & 4 & 4 & 4 & 4 & 4 & 4 & 4 & 4 & 44 \\
\hline $\begin{array}{l}\text { Order } \\
\text { (unit) }\end{array}$ & 4 & 4 & 4 & 4 & 4 & 4 & 4 & 4 & 4 & 4 & 4 & & 44 \\
\hline $\begin{array}{c}\text { shortage } \\
(\text { unit })\end{array}$ & 4 & & & & 1 & & 1 & 2 & 1 & 1 & & 1 & 11 \\
\hline
\end{tabular}

2) MRP Brake Goodrich

a) Input Sistem MRP

Tabel 4.10 MPS Brake Goodrich

\begin{tabular}{|l|c|c|c|c|c|c|c|c|c|c|c|c|}
\hline Periode & 1 & 2 & $\mathbf{3}$ & $\mathbf{4}$ & $\mathbf{5}$ & $\mathbf{6}$ & $\mathbf{7}$ & $\mathbf{8}$ & $\mathbf{9}$ & $\mathbf{1 0}$ & $\mathbf{1 1}$ & $\mathbf{1 2}$ \\
\hline $\begin{array}{l}\text { Brake } \\
\text { Goodrich }\end{array}$ & 5 & 5 & 5 & 5 & 4 & 4 & 5 & 5 & 4 & 5 & 5 & 4 \\
\hline
\end{tabular}

Tabel 4.11 Data Persediaan Brake Goodrich

\begin{tabular}{|c|c|}
\hline Bulan & $\begin{array}{c}\text { Stock On Hand,Schedule Receipt,AI } \\
\text { Stock }\end{array}$ \\
\hline Januari & 1 \\
\hline Febuari & 4 \\
\hline Maret & 4 \\
\hline April & 4 \\
\hline Mei & 4 \\
\hline Juni & 4 \\
\hline Juli & 4 \\
\hline Agustus & 4 \\
\hline September & 4 \\
\hline Oktober & 4 \\
\hline November & 4 \\
\hline Desember & 4 \\
\hline
\end{tabular}

\section{b. Output Sistem MRP}

Tabel 4.12 MRP Brake Goodich

\begin{tabular}{|c|c|c|c|c|c|c|c|c|c|c|c|c|c|}
\hline \multicolumn{13}{|c|}{ Minimum Stock $=2 \quad$ Maksimum Stock $=4 \quad$ ROP $=3$} & \multirow{2}{*}{$\begin{array}{c}\text { Total } \\
12\end{array}$} \\
\hline $\begin{array}{c}\text { Bulan } \\
\text { (Periode) }\end{array}$ & 1 & 2 & 3 & 4 & 5 & 6 & 7 & 8 & 9 & $\begin{array}{l}1 \\
\mathbf{0}\end{array}$ & $\begin{array}{l}1 \\
1\end{array}$ & $\begin{array}{l}1 \\
2 \\
\end{array}$ & \\
\hline $\begin{array}{c}\text { Demand } \\
(\text { Unit })\end{array}$ & 5 & 5 & 5 & 5 & 4 & 4 & 5 & 5 & 4 & 5 & 5 & 4 & 56 \\
\hline $\begin{array}{c}\text { On Hand,AI } \\
\text { Stock,Schedul } \\
\text { e Receipt(unit) }\end{array}$ & 1 & 4 & 4 & 4 & 4 & 4 & 4 & 4 & 4 & 4 & 4 & 4 & 0 \\
\hline $\begin{array}{c}\text { Replenishment } \\
\text { (unit) }\end{array}$ & & 4 & 4 & 4 & 4 & 4 & 4 & 4 & 4 & 4 & 4 & 4 & 40 \\
\hline Order (unit) & 4 & 4 & 4 & 4 & 4 & 4 & 4 & 4 & 4 & 4 & 4 & & 44 \\
\hline shortage (unit) & 4 & 1 & 1 & 1 & & & 1 & 1 & & 1 & 1 & & 11 \\
\hline
\end{tabular}

\section{ANALISIS HASIL}

a. Analisis Umur Brake

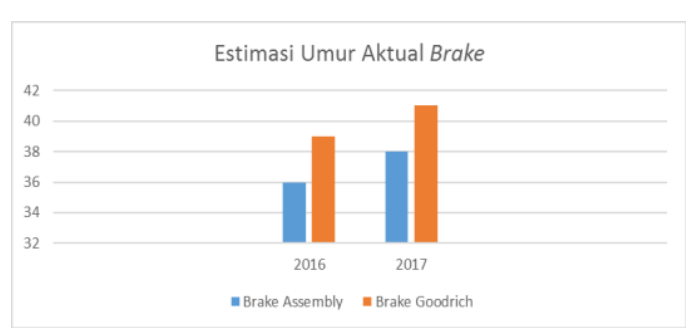

Gambar 5.1 Estimasi Umur Aktual Brake

Dari hasil perhitungan dapat diketahui hasil perhitungan estimasi umur aktual brake pada tahun 2016 untuk carbon brake assembly yaitu 36 hari,serta umur brake Goodrich yaitu 39 hari. Sedangkan perhitungan hasil forecasting untuk tahun 2017 menunjukan bahwa umur brake assembly 38 hari, dan 41 hari untuk brake Goodrich. Pada grafik diketahui bahwa pada saat usia brake mencapai batas maksimal nya maka harus dilakukan removal brake assembly yang terinstall pada pesawat B737-800 NG. Jika dilihat dari hasil estimasi di atas, maka dapat dikatakan umur (usia pakai) suatu komponen bergantung pada jenis komponen nya. Faktor internal yang biasanya mempengaruhi umur komponen brake adalah tingkat reliability ataupun keandalan suatu brake serta serangkaian proses yang terlibat dalam sistem kerja komponen brake. Sementara faktor eksternal yang dapat mempengaruhi seperti kasarnya pacuan landasan yang di gunakan pesawat untuk melakukan pendaratan, serta perlakuan pilot yang mengoperasikan pesawat. 


\section{b. Analisis Estimasi Jumlah Removal Brake}

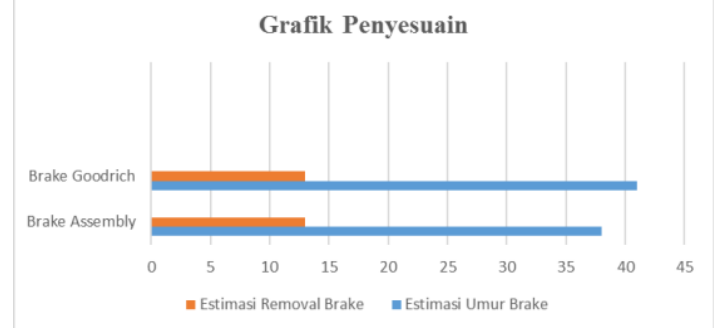

Gambar 5.2

Penyesuain Umur Brake dan Jumlah Brake Removal

Berdasarkan grafik di atas terlihat perbandingan umur brake dalam satuan hari dan jumlah brake yang removal dalam satuan unit. Berdasarkan hasil forecasting di peroleh nilai estimasi brake yang akan removal pada tahun 2017 yaitu sebanyak 13 brake untuk masing-masing jenis brake. Hal ini dapat dikatakan hasil perhitungan estimasi jumlah removal brake hampir sesuai dengan perhitungan umur aktual dua jenis brake tersebut.

\section{c. Analisa Estimasi Jadwal Removal Brake}

Penentuan estimiasi kapan suatu brake akan removal (diturunkan) dari pesawat dapat diketahui dari perhitungan umur aktual brake di tambah dengan waktu penginstallan brake terakhir di suatu pesawat, dalam hal ini pesawat yang diteliti yaitu pesawat jenis B737-800 NG. Diketahui dari perhitungan bahwa untuk brake jenis assembly diperkirakan akan removal pada 21/12/2016 dan untuk brake jenis goodrich akan removal pada 11/12/2016. Hasil estimasi perhitungan ini di pakai sebagai dasar penentuan untuk mempersiapkan brake yang serviceable pada saat di butuhkan oleh suatu pesawat.

\section{d. Analisis Perbandingan Forecast Metode Regresi Linier dan Exponentail Smoothing} 1) Brake Assembly

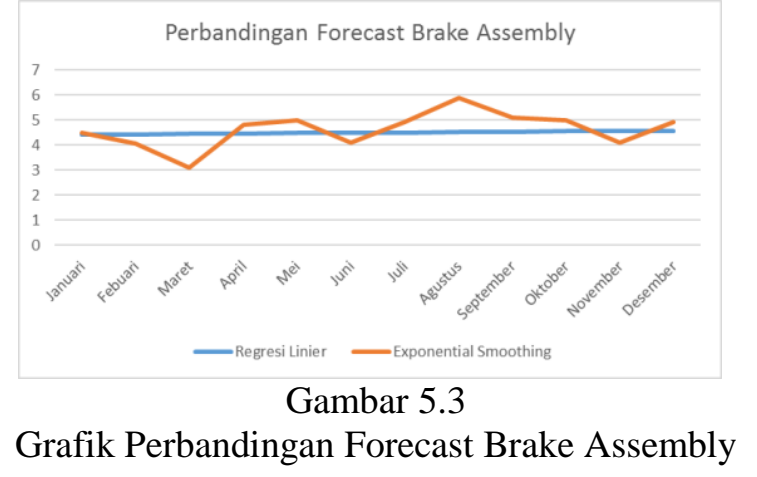

Grafik di atas menunjukan bagaimana perbandingan hasil forecast dengan menggunakan 2 metode yang berbeda. Pada gambar 4.11 merupakan grafik hasil perhitungan forecast dengan metode regresi linier dan forecast dengan exponential smoothing untuk brake assembly. Terlihat bahwa pola data forecasting regresi linier cendrung konstan pada 6 bulan periode awal, namun mengalami kenaikan pada periode selanjutnya dan tetap konstan pada angka tersebut hingga akhir periode permalan. Sedangkan forecasting dengan exponential smoothing cenderung fluktuatif di sekitar nilai ratarata demand real pada tahun 2016. Hal ini menunjukan bahwa metode forecast exponential smoothing menghasilkn nilai peramalan yang lebih sesuai dan tepat jika dilihat dari pota data peramalan yang dihasilkan. Tahapan forecasting permintaan brake assembly ini menjadi tahapan yang sanga penting mengingat bahwa tingkat pemenuhan kebutuhan brake sangat di tentukan pada proses perencanaan komponen yang akan di supply untuk kebutuhan maintetnance.

\section{2) Brake Goodrich}

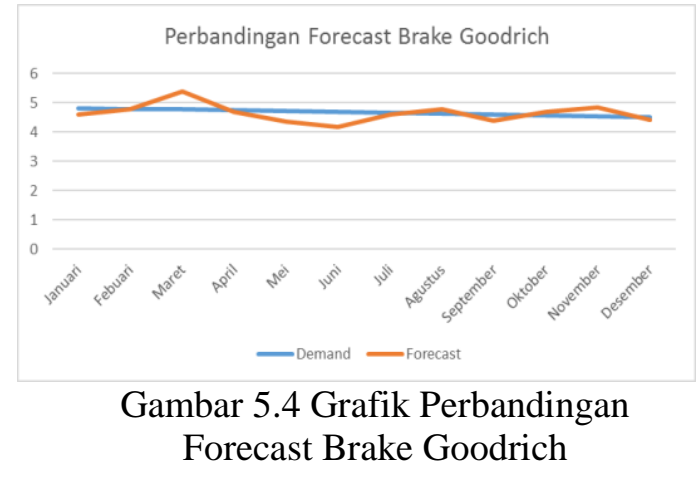

Pada gambar 6.4 merupakan grafik perbandingan hasil perhitungan forecast regresi linier dengan metode single exponential smoothing pada brake goodrich. Pada gambar terlihat bahwa pola data berdasarkan metode regresi linier konstan dari awal periode hingga akhir, sedangkan forecasting dengan metode exponential smoothing relatif mengikuti permintaan periode sebelumnya dan berfluktuatif di sekitar garis demand real. Pada metode single exponential ini, di lakukan perhitungan tentang nilai error (kesalahan) dalam permalan terlebih dahulu, kemudian di tentukan nilai konstanta kroston yang paling kecil nilai nya, lalu besar konstanta tersebut di jadikan patokan dalam perhitungan forecasting permintaan periode mendatang.

Dari kedua analisis tersebut, dapat di simpulkan bahwa pemilihan metode peramalan sangat penting di lakukan utuk mendapatkan hasil permalan yang paling optimal agar dapat memenuhi kebutuhan untuk periode mendatang, serta menghindari kerugian yang mungkin ditimbulkan karena terjadi shortage (kekurangan stock). Oleh karena itu, pada penelitian ini penulis memberikan masukan kepada perusahaan untuk menggunkan metode single exponential smoothing dalam melakukan peramalan kebutuhan sparepart ataupun komponen untuk pesawat. 


\section{e. Analisis MRP}

Analisis MRP dilakukan untuk mencari solusi untuk pemenuhan kebutuhan material yang harus ada serta untuk membandingkan kebijakan yang di terapkan di PT ABC dengan perhitungan menggunakan metode MRP. Berikut akan di sajikan grafik perbandingan shortage brake metode exsisting perusahaan dengan metode MRP

\section{1) Brake Assembly}

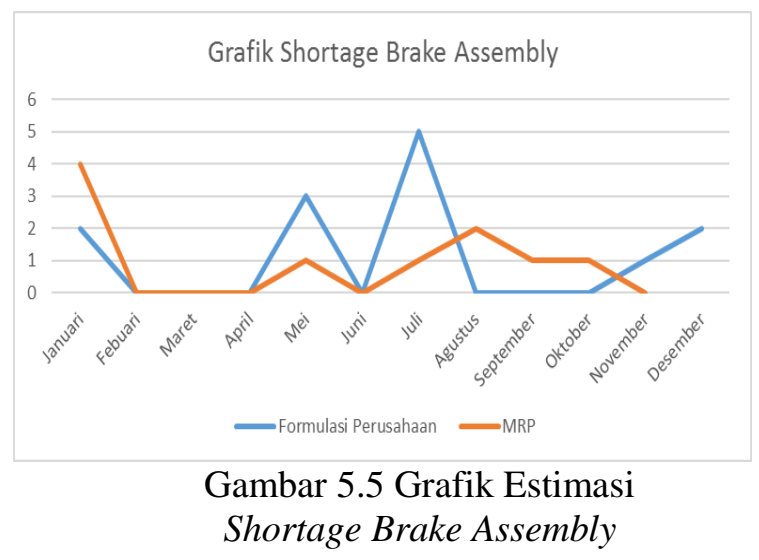

Berdasarkan grafik estimasi shortage di atas dapat dilihat bahwa rata-rata jumlah shortage yang lebih tinggi terjadi pada saat perhitungan shortage berdasarkan metode perusahaan. Hal ini dapat diketahui dari lonjakan grafik yang terjadi pada bulan mei, juli, dan desember yang jauh lebih tinggi jika di bandingkan dengan perhitungan shortage dengan MRP. Adapun jumlah total shortage berdasarkan metode perusahaan sebanyak 13 unit dan jumlah total shortage berdasarkan MRP sebanyak 11 unit untuk periode 1 tahun. Namun berdasarkan metode MRP, perusahaan akan mengalami shortage yang cukup tinggi pada periode awal (bulan januari) yaitu terjadi kekurangan stock persediaan sebanyak 4 unit. Tetapi keadaan shortage pada awal periode tidak mempengaruhi jumlah shortage pada periode berikutnya karena berdasarkan perhitungan MRP jumlah shortage cenderung menurun dan tidak terjadi pada setiap bulan.

\section{2) Brake Goodrich}

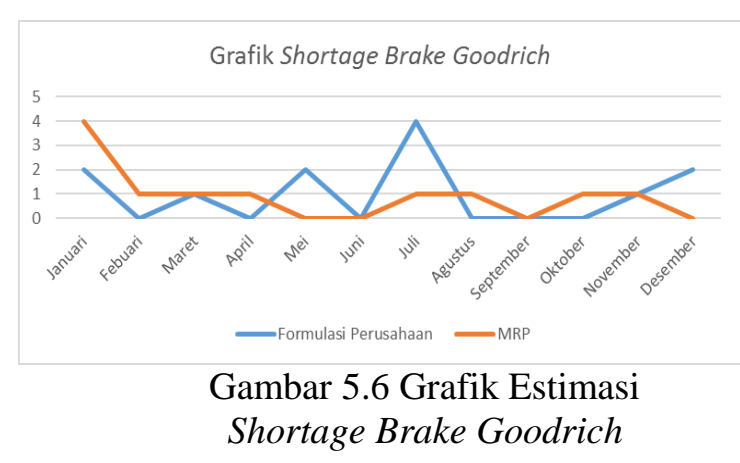

Berdasarkan grafik estimasi shortage di atas dapat dilihat bahwa rata-rata jumlah shortage yang lebih tinggi terjadi pada saat perhitungan shortage berdasarkan metode perusahaan. Hal ini dapat diketahui dari lonjakan grafik yang terjadi pada bulan mei, juli, dan desember yang jauh lebih tinggi jika di bandingkan dengan perhitungan shortage dengan MRP. Adapun jumlah total shortage berdasarkan metode perusahaan sebanyak 12 unit dan jumlah total shortage berdasarkan MRP sebanyak 11 unit untuk periode 1 tahun namun berdasarkan metode MRP, perusahaan akan mengalami shortage yang cukup tinggi pada periode awal (bulan januari) yaitu terjadi kekurangan stock persediaan sebanyak 4 unit. Tetapi keadaan shortage pada awal periode tidak mempengaruhi jumlah shortage pada periode berikutnya karena berdasarkan perhitungan MRP jumlah shortage cenderung menurun dan tidak terjadi pada setiap bulan.

\section{KESIMPULAN}

Berdasarkan hasil penelitian tentang pengadaan komponen rem pesawat pada pesawat B737-800 NG maka di dapatkan kesimpulkan sebagai berikut :

a. jumlah permintaan komponen carbon brake assembly sebesar 13 unit/tahun dan 13 unit/tahun untuk brake goodrich. Angka ini dapat dilihat dari hasil estimasi jumlah brake yang akan removal.

b. Estimasi umur brake assembly berdasarkan hasil forecast yaitu 38 hari, sedangkan brake goodrich memiliki umur pakai selama 41 hari. Umur pakai brake berbnding terbalik dengan jumlah permintaan brake yang harus disediakan yaitu apabila umur pakai komponen lebih lama maka jumlah persediaan yang harus di penuhi akan semakin sedikit

c. Estimasi jadwal removal brake yaitu tanggal terakhir peng installan brake di tambah dengan umur aktual brake yang telah di tentukan yaitu tanggal 21 bulan 12 untuk brake assembly dan tanggal 2 bulan 11 untuk brake goodrich.

d. Metode Peramalan single exponential smoothing menghasilkan nilai estimasi permintaan brake yang cendrung mengikuti pola data permintaan real atau berfluktuatif di sekitar nilai permintaan (demand) brake masing-masing.

\section{DAFTAR PUSTAKA}

Bussmann, J., Schmidt, T., dan Bauer, A. 2007 Strategies and Tactics in Supply Chain Event Management: Proactive Event Management in the Supply Chain of Aircraft Spareparts. Germany: Springer Berlin Heidelberg.

Frechtling,Douglas. 2012 . Forecasting Tourism Demand. Oxford

Heisig,Gerald. 2012. Planning Stability in MRP System. Magdeburg,Germany 
http://dokumen.tips/documents/landing-gear-

main.html

https://ilmuteknikindustri.wordpress.com/2011/02/0

4/perencanaan-teknik-industri/

http://one-ilmuterbang.blogspot.co.id/

Kilpi, J. 2008. Sourcing of Availability Services: Case Aircraft Components Support. Eversion Helsinki School of Economics Working Paper. Finlandia: HSE Print 2008.

Kinnison,Harry. 2012.Aviation Maintenance Management Second Edition. New York. McGraw Hill.

Koeswara, Sony. Suhada,Taruna Resa. Jurnal Perencanaan Kebutuhan Material Metode Lot Sizing. Jakarta

Koval,Doon O., Chowdury Ali. 2009. Power Distrbution System Reliability. United States,America 